\title{
Kejadian Atopi pada Bayi Usia 6 Bulan yang Mendapat Kombinasi ASI dan Susu Formula Mengandung Probiotik dan Nonprobiotik
}

\author{
Tetty Yuniati, Abdurachman Sukadi \\ Departemen Ilmu Kesehatan Anak \\ Fakultas Kedokteran Universitas Padjadjaran-Rumah Sakit Dr. Hasan Sadikin, Bandung
}

\begin{abstract}
Abstrak
Kelahiran seksio sesarea menyebabkan terlambatnya kolonisasi flora usus sehingga akan meningkatkan kejadian atopi. Probiotik menstimulasi respons imun sehingga akan menurunkan kejadian atopi. Tujuan penelitian ini untuk menentukan apakah terdapat perbedaan kejadian atopi pada bayi yang diberikan kombinasi ASI dengan susu formula yang mengandung probiotik dan tanpa probiotik. Randomized open label clinical trial dilakukan selama periode November 2009 sampai Oktober 2010 terhadap 96 bayi normal, berat badan lahir $\geq 2.500 \mathrm{~g}$, lahir dengan seksio sesarea di RS Dr. Hasan Sadikin Bandung. Sejak lahir, selama 4 minggu sebanyak 48 bayi diberikan kombinasi ASI dan susu formula probiotik dan 48 bayi sebagai kontrol, selanjutnya pemberian minuman bergantung pada orangtua. Dilakukan pencatatan lama menyusui, jumlah formula, dan faktor risiko atopi. Skin prick test dilakukan pada usia 6 bulan. Diagnosis atopi ditegakkan jika terbentuk wheal $\geq 4 \mathrm{~mm}$. Analisis statistik dilakukan dengan chi-square untuk data kategori dan uji t untuk data numerik. Lama menyusui, jumlah formula, dan faktor risiko atopi tidak berbeda secara bermakna pada kedua kelompok $(p>0,05)$. Reaksi atopi ditemukan positif pada $4 / 23$ bayi yang mendapat probiotik dan $10 / 28$ bayi tanpa probiotik $(\mathrm{p}>0,05)$. Disimpulkan bahwa kejadian atopi tidak berbeda antara kelompok yang diberikan ASI dan susu formula mengandung probiotik dan tidak mengandung probiotik. [MKB. 2011;43(2):55-9].
\end{abstract}

Kata kunci: Atopi, kelahiran seksio sesarea, probiotik

\section{Atopic Occurence on Six-month-old Infants between Probiotic Formula-fed and Non Probiotic Formula-fed Healthy Born by Cesarean Delivery}

\begin{abstract}
Cesarean delivery might delayed the colonization of newborn intestine and increase atopic disorders. Probiotic shown to stimulate immune responses, which has implied in the development of atopic disorders. The aim of the study was to find out the difference of atopic occurence in breastfed infants born by cesarean delivery given probiotic formula and non probiotic formula. Randomized open label clinical trial was performed on 96 healthy infants, birth weight $\geq 2,500 \mathrm{~g}$, born by cesarean delivery in Dr. Hasan Sadikin Hospital Bandung during November 2009 to October 2010. Since birth, 48 infants were breastfed combined with probiotic formula and 48 infants as control group for 4 weeks and afterwards the feeding pattern depend on the parents. Skin prick test reaction was performed at 6 months old and atopy was diagnosed if the wheal $\geq 4 \mathrm{~mm}$. Statistical analysis using chi-square and t-test. The duration of daily breastfeeding, amount of formula and risk factor for atopic disorders were not significantly different in both groups ( $p>0.05$ ). Atopy were positive in $4 / 23$ infants with probiotic and $10 / 28$ infants positive without probiotic. It was not significantly different $(p>0.05)$. Conclusion, the atopic occurence is not different at 6 months-old receiving breastmilk with probiotic and non probiotic formula. [MKB. 2011;43(2):55-9].
\end{abstract}

Key words: Atopy, caesarean delivery, probiotic

Korespondensi: Tetty Yuniati, dr., Sp.A(K), Departemen Ilmu Kesehatan Anak, Fakultas Kedokteran Unpad-Rumah Sakit Dr. Hasan Sadikin, jalan Pasteur 38 Bandung, telepon 2035957, mobile 08122018506, e-mail: tetty_yusuf@yahoo.co.id 


\section{Pendahuluan}

Kejadian seksio sesarea (SS) di dunia akhir-akhir ini meningkat dengan cepat dan menurut data survei Nasional pada tahun 2007 sebesar 22,8\% dari seluruh persalinan. ${ }^{1}$ Bayi yang lahir melalui SS lebih rentan untuk mengalami morbiditas, antara lain laserasi, sindrom gawat napas, dan meningkatnya kejadian atopi..$^{2-4}$ Bayi yang lahir dengan SS mempunyai kolonisasi flora usus yang berbeda dengan kelahiran vagina. ${ }^{5-8}$ Perubahan kolonisasi flora usus pada bayi yang lahir dengan SS akan mempengaruhi maturasi sistem imun yang akan meningkatkan risiko penyakit atopi di kemudian hari., , $^{-11}$

Pemberian probiotik ini bertujuan untuk mengembalikan komposisi normal mikrobiota usus, sehingga akan mengurangi gejala atopi. ${ }^{12-16}$ Sampai saat ini belum diketahui bagaimana pengaruh probiotik terhadap kejadian atopi pada bayi lahir SS yang berasal dari keluarga yang tidak mempunyai riwayat atopi pada 6 bulan pertama kehidupan.

Tujuan penelitian ini adalah untuk mengetahui apakah terdapat perbedaan kejadian atopi pada bayi usia 6 bulan yang mendapat ASI dan formula mengandung probiotik dibandingkan dengan bayi yang mendapat ASI dan susu formula tidak mengandung probiotik.

\section{Metode}

Subjek adalah bayi yang lahir di Departemen Ilmu Kesehatan Anak RS Dr. Hasan Sadikin Bandung periode November 2009-Oktober 2010 dengan kriteria inklusi adalah bayi normal, cukup bulan, sehat, lahir secara SS dengan berat badan lahir $\geq 2.500$ g serta keluarga tidak mempunyai riwayat alergi dengan menggunakan kuesioner alergi yang dikeluarkan oleh IDAI (2007). Subjek penelitian ini merupakan subjek dari penelitian yang berjudul "Dampak pemberian B. lactis terhadap mikrobiota feses, marker imun dan SigA feses pada bayi yang lahir dengan seksio sesarea". Metode yang digunakan adalah randomized open label clinical trial. Subjek secara permutated random dibagi menjadi dua kelompok, yaitu kelompok pertama mendapat kombinasi ASI serta susu formula mengandung probiotik dan kelompok kedua adalah bayi yang mendapat kombinasi ASI dan susu formula tidak mengandung probiotik sejak lahir sampai usia 4 minggu dan saat usia 4 minggu dilakukan pemeriksaan TGF- $\beta$ darah. Setiap hari dilakukan pencatatan lama menyusui dan jumlah formula yang dihabiskan bayi sampai usia 4 minggu. Selain itu, setiap minggu dilakukan pemeriksaan fisis, pengukuran berat badan, dan kejadian penyakit. Setelah 4 minggu sampai usia 6 bulan, jenis minuman susu ditentukan oleh orangtua dan saat usia 5 bulan dikirim surat untuk diminta datang ke Departemen Ilmu Kesehatan Anak RS Dr. Hasan Sadikin Bandung pada usia sekitar 6 bulan. Pada usia 6 bulan \pm 2 minggu diberikan kuesioner tentang jenis susu yang diminum, penyakit yang dialami, imunisasi, dan faktor risiko alergi, yaitu jumlah saudara kandung, pemakaian karpet, alas tidur dan binatang peliharaan, serta dilakukan uji tusuk kulit. Atopi ditegakkan apabila hasil uji tusuk kulit positif terhadap salah satu alergen yang membentuk wheal berukuran $\geq 4 \mathrm{~mm}$. Alergen berjumlah 12 macam, yaitu Blomia tropicalis, Dermatophagoides pteronyssimus, Dermatophagoides farinae, Alternaria alternata, Aspergillus mis, bulu kucing, putih telur, kuning telur, coklat, udang, protein kedelai, dan kecoa.

Jumlah sampel ditentukan berdasarkan biaya dan waktu. Perbedaan faktor risiko atopi dan kejadian atopi pada bayi yang mendapat formula mengandung probiotik dan tidak mengandung probiotik dianalisis untuk data kategorik menggunakan chi-square dan data numerik uji t. Kemaknaan ditentukan berdasarkan $\mathrm{p}<0,05$ dengan piranti lunak SPSS 17.0.

\section{Hasil}

Selama periode penelitian di Rumah Sakit Dr. Hasan Sadikin lahir 265 bayi dengan SS mempergunakan bius total dan ibu yang meminta pemberian susu formula sebanyak 108 orang yang dibagi menjadi dua kelompok, yaitu

Tabel 1 Karakteristik 51 Subjek yang Ikut Serta Penelitian berdasarkan Status Randomisasi

\begin{tabular}{ccc}
\hline Karakteristik & Probiotik (n=23) & Nonprobiotik (n=28) \\
\cline { 2 - 3 } Jenis kelamin & $\mathbf{n}(\mathbf{0})$ atau Rata-rata \pm SB \\
Laki-laki & $16(70)$ & $17(61)$ \\
Perempuan & $7(30)$ & $11(39)$ \\
Usia kehamilan (minggu) & $38,30 \pm 0,56$ & $38,46 \pm 0,69$ \\
Usia ibu (tahun) & $30 \pm 5,07$ & $30 \pm 5,33$ \\
Berat badan lahir (g) & $3.201 \pm 378,95$ & $3.230 \pm 370,18$ \\
Berat badan usia 6 bulan (g) & $7.598 \pm 774,18$ & $7.493 \pm 678,28$ \\
\hline
\end{tabular}


Tetty: Kejadian Atopi pada Bayi Usia 6 Bulan yang Mendapat Kombinasi ASI dan Susu Formula Mengandung Probiotik

Tabel 2 Karakteristik 51 Subjek Penelitian yang berhubungan dengan Kejadian Atopi

\begin{tabular}{|c|c|c|c|}
\hline \multirow{2}{*}{$\begin{array}{l}\text { Karakteristik } \\
\text { Faktor Risiko }\end{array}$} & Probiotik $(n=23)$ & Nonprobiotik $(n=28)$ & \multirow{2}{*}{$\mathbf{p}$} \\
\hline & \multicolumn{2}{|c|}{ n (\%) atau Rata-rata \pm SB } & \\
\hline $\begin{array}{l}\text { Lama menyusui selama } 4 \\
\text { minggu (menit) }\end{array}$ & $2.789 \pm 1308,52$ & $3.055 \pm 1,515,22$ & $0,512 * *$ \\
\hline $\begin{array}{l}\text { Jumlah susu formula } \\
\text { selama } 4 \text { minggu (mL) }\end{array}$ & $7.029 \pm 2031,57$ & $6.583 \pm 1,320,17$ & $0,496^{*}$ \\
\hline TGF- $\beta$ usia 4 minggu $(\mathrm{pg} / \mathrm{mL})$ & $38.450 \pm 7.752,019$ & $35.600 \pm 11.338,823$ & $0,311 * *$ \\
\hline \multicolumn{4}{|l|}{ Alas tidur } \\
\hline Kapuk & $3(13)$ & $6 \quad(21)$ & $0,680 *$ \\
\hline Busa & $20 \quad(87)$ & $22(79)$ & \\
\hline \multicolumn{4}{|l|}{ Menggunakan karpet } \\
\hline Ya & $8 \quad(35)$ & $10(36)$ & $1,000^{*}$ \\
\hline Tidak & $15(65)$ & 18 (64) & \\
\hline \multicolumn{4}{|l|}{ Jenis minum pascausia 4} \\
\hline minggu & $8 \quad(35)$ & $13(46)$ & $0,400 *$ \\
\hline ASI+susu fomula & $15(65)$ & $15(54)$ & \\
\hline \multicolumn{4}{|l|}{ Memelihara binatang } \\
\hline $\mathrm{Ya}$ & $4 \quad(17)$ & $3(11)$ & $0,779 *$ \\
\hline Tidak & $19(83)$ & $25 \quad(89)$ & \\
\hline \multicolumn{4}{|l|}{ Saudara kandung } \\
\hline $\mathrm{Ya}$ & $16(70)$ & $20 \quad(71)$ & $0,884 *$ \\
\hline Tidak & $7 \quad(30)$ & 8 (29) & \\
\hline \multicolumn{4}{|l|}{ Vaksinasi } \\
\hline Lengkap & $23(100)$ & $28(100)$ & \\
\hline Tidak lengkap & $0(0)$ & $0 \quad(0)$ & \\
\hline
\end{tabular}

kelompok kombinasi ASI dengan susu formula probiotik dan kelompok ASI dengan susu formula nonprobiotik, masing-masing kelompok sebanyak 54 orang. Pada follow-up selama 4 minggu sebanyak 12 orang drop out, sehingga masing-masing kelompok menjadi 48 orang. Pada usia 6 bulan \pm 2 minggu jumlah subjek yang datang adalah 51 bayi yang orangtuanya bersedia anaknya diikutsertakan dalam penelitian. Pemeriksaan uji tusuk kulit dilakukan pada 23 orang yang mendapat kombinasi ASI dan susu formula mengandung probiotik serta 28 orang yang mendapat kombinasi ASI dan susu formula tidak mengandung probiotik.

Tabel 1 menunjukkan bahwa jumlah laki-laki pada kelompok probiotik 9\% lebih tinggi dari ke- lompok nonprobiotik, sedangkan jumlah perempuan sebaliknya. Usia kehamilan dan berat badan lahir pada kedua kelompok sesuai dengan salah satu kriteria subjek penelitian. Kenaikan berat badan sampai usia 6 bulan pada kedua kelompok meningkat sesuai dengan pola pertumbuhan berat badan yang normal.

Tabel 2 memperlihatkan faktor lingkungan yang berhubungan dengan kejadian atopi.

Lama menyusui dan jumlah susu formula dalam 4 minggu pertama kehidupan dicatat setiap minggu oleh orangtua pada kedua kelompok dan tidak menunjukkan perbedaan yang bermakna. Kadar TGF- $\beta$ pada usia 4 minggu pada kelompok probiotik lebih tinggi dibandingkan dengan nonprobiotik, tetapi tidak berbeda bermakna. Alas

Tabel 3 Hubungan Pemberian Susu Formula Mengandung Probiotik dengan Kejadian Atopi pada Usia 6 Bulan \pm 2 Minggu

\begin{tabular}{cccc}
\hline Atopi & $\begin{array}{c}\text { Probiotik } \\
(\mathbf{n = 2 3 )}\end{array}$ & $\begin{array}{c}\text { Nonprobiotik } \\
(\mathbf{n = 2 8})\end{array}$ & $\mathbf{p}$ \\
\hline Negatif & 19 & 18 & 0,253 \\
Positif & 4 & 10 & \\
\hline
\end{tabular}

Keterangan: * Analisis menggunakan uji chi-square 
tidur, menggunakan karpet, jenis minuman pascausia 4 minggu, memelihara binatang, memiliki saudara kandung serta vaksinasi lengkap yang didapat secara kuesioner pada usia 6 bulan tidak berbeda bermakna antara kedua kelompok.

Hasil analisis kejadian atopi antara kelompok susu formula mengandung probiotik dan tidak mengandung probiotik dapat dilihat pada Tabel 3.

Tabel 3 menunjukkan hubungan kejadian atopi pada bayi yang mendapat probiotik dan nonprobiotik yang dianalisis menggunakan chi-square dengan koreksi kontinuitas, tidak berbeda bermakna antara kelompok yang mendapat probiotik dan nonprobiotik $(\mathrm{p}=0,253)$.

\section{Pembahasan}

Hasil penelitian ini menunjukkan bahwa kejadian atopi pada bayi yang diberikan kombinasi ASI dan formula mengandung probiotik dibandingkan dengan yang mendapat susu formula tidak mengandung probiotik tidak berbeda bermakna (Tabel 3).

Flora usus pada bayi yang lahir dengan SS, didominasi oleh Clostridium spp. dan Bacteroides spp., Enterobacteria serta Enterococci, sedangkan Bifidobacterium ditemukan dalam jumlah sedikit, sehingga perubahan kolonisasi flora usus ini akan mengubah respons imun. ${ }^{5-8}$ Sampai saat ini telah diketahui bahwa pemberian probiotik akan mempengaruhi respons imun, yaitu probiotik menimbulkan rangsangan imunomodulasi sistem imun saluran cerna dan juga akan meringankan gejala atopi pada anak yang menderita atopi. . $^{12,13,15}$ Adanya probiotik pada mukosa dan epitel usus akan membentuk komponen bioaktif yang memproduksi sitokin dan kemokin. Peptidoglikan pada dinding probiotik berfungsi sebagai antigen yang selanjutnya akan terbentuk subset sel $\mathrm{T}$, yaitu Th3 dan sel ini memproduksi TGF- $\beta$ dan berperan sebagai supresi aktif yang menyebabkan timbulnya toleransi oral. Toleransi ini yang sebagian dimediasi di saluran cerna dan hati mengurangi respons imun overaktif yang terjadi pada alergi. ${ }^{15}$ Bayi lahir SS yang mendapat susu formula yang mengandung probiotik selama empat minggu diharapkan akan dapat mengubah flora usus yang didominasi oleh Clostridium menjadi Bifidobacterium, sehingga akan mengurangi kejadian alergi. Pada penelitian ini kejadian atopi pada kedua kelompok tidak berbeda, hal ini kemungkinan karena subjek penelitian ini masih mendapat ASI sampai usia 6 bulan. Selain itu, kadar TGF- $\beta$ pada usia 4 minggu juga menunjukkan hasil yang tidak berbeda pada kedua kelompok tersebut. Telah diketahui bahwa ASI akan mempengaruhi respons imun, sehingga akan mempengaruhi kejadian atopi. ${ }^{14}$ Zat kekebalan yang terdapat dalam ASI antara lain Lactobacillus bifidus, secretory $\operatorname{Ig} \mathrm{A}$ ( $\mathrm{s} \operatorname{Ig} \mathrm{A})$, lisozim, laktoperoksidase, dan leukosit akan menurunkan risiko infeksi saluran pencernaan, saluran pernapasan, infeksi telinga, diabetes melitus, dan penyakit alergi. ${ }^{17,18}$ Bayi yang mendapat ASI memiliki profil mikrobiota yang didominasi oleh Bifidobacterium dan Lactobacillus, sedangkan pada bayi yang diberi susu formula adalah Coliform, Enterococi, dan Bacteroides. ${ }^{7,8}$ Hal ini menyiratkan ASI mungkin memiliki faktor yang berperan dalam terbentuknya mikrobiota usus yang baik. Selain itu didukung juga dengan bukti bahwa ASI pada bayi yang mengalami ekzem atopi memilikikonsentrasi antiinflamasi TGF- $\beta$ yang lebih rendah dibandingkan dengan ASI ibu yang anaknya tetap sehat selama proses laktasi ini. ${ }^{15}$ Suplementasi probiotik pada ibu sebelum persalinan dan selama kehamilan akan meningkatkan kadar TGF- $\beta$ dalam ASI-nya kelak dan menurunkan angka kejadian ekzem atopi. ${ }^{19}$ Kelemahan penelitian ini adalah pemberian probiotik pada bayi yang mendapat ASI, idealnya dilakukan pada bayi yang diberikan tanpa ASI, akan tetapi hal ini sulit dilakukan dan selain itu tidak etis.

Faktor lingkungan juga berpengaruh pada kejadian atopi. ${ }^{19,20}$ Faktor-faktor yang berhubungan dengan kejadian atopi (Tabel 2) tidak berbeda bermakna, sehingga faktor-faktor tersebut tidak diikutsertakan dalam analisis untuk menentukan perbedaan kejadian atopi di antara kedua kelompok.

Pada penelitian ini subjek yang dipilih adalah bayi yang lahir dari keluarga yang tidak mempunyai riwayat alergi. Pada keluarga yang mempunyai riwayat atopi, kejadian atopi pada anaknya adalah $60 \%$, sedangkan yang tidak mempunyai riwayat atopi sebesar $10 \% .{ }^{20}$ Dengan demikian walaupun penelitian ini menggunakan subjek yang berasal dari keluarga yang tidak mempunyai riwayat atopi, atopi masih dapat terjadi. Pada kelompok probiotik ditemukan 4 atopi dari 23 subjek, sedangkan kelompok nonprobiotik ditemukan 10 atopi dari 23 subjek.

Disimpulkan tidak ada perbedaan kejadian atopi pada bayi yang mendapat kombinasi ASI dan susu formula yang mengandung probiotik dibandingkan dengan bayi yang mendapat kombinasi ASI dan susu formula tidakmengandung probiotik. Disarankan dilakukan penelitian lebih lanjut untuk menentukan pengaruh probiotik terhadap kejadian atopi pada bayi yang kurang mendapat ASI dari ibunya pada usia 1 bulan atau lebih.

\section{Daftar Pustaka}

1. Departemen Kesehatan RI. Laporan Hasil Riset Kesehatan Dasar (RisKesDas) Nasional. Jakarta: Badan Penelitian dan 
Pengembangan Kesehatan; 2008.

2. Mukherjee S. Rising cesarean sections rate. J Obstetr Gynecol India. 2006;56:298-300.

3. Laubereau B, Filipiak B, Von Berg A, Reinhardt D, Wichmann H, Koletzko S. Caesarean section and gastrointestinal symptoms, atopic dermatitis, and sensitisation during the first year of life. Arch Dis Child. 2004;89:993-7.

4. Polster H, David M, Buist A, Volmert W, O'Connor E, Frazier E, dkk. Caesarean section delivery and the risk of allergic disorders in childhood. Clin Exp Allergy. 2005;35:1466-72.

5. Bezkorovainy A. Probiotics: determinants of survival and growth in the gut. Am J Clin Nutr. 2001;73:399-405.

6. Fooks L, Gibson G. Probiotics as modulators of the gut flora. Br J Nutr. 2002;88:39-49.

7. Kiani L. Bugs in our guts - not all bacteria are bad: how probiotics keep us healthy. CSA Discovery Guides. 2006;39:1-9.

8. Penders J, Thijs C, Vink C. Factors influencing the composition of the intestinal microbiota in early infancy. Pediatrics. 2006;118:511-21.

9. Xu B, Pekkanen J, Hartikainen A, Jarvelin MR. Caesarean section and risk of asthma and allergy in adulthood. J Allergy Clin Immunol. 2001;107:702-3.

10. Tolanes MC, Moster D, Daltveit AK, Irgens LM. Cesarean section and risk of severe childhood asthma: a population based cohort Study. J Pediatr. 2009;153:112-6.

11. Park YH, Kim KW, Choi BS, Jee HM, Sohn MH, Kim KEW. Relationship between mode of delivery in childbirth and prevalence of allergis diseases in Korea children. Allergy Asthma Immunol Res. 2010 January;2(1):28-33.

12. Taylor AL, Halle J, Wilschut J, Lechmann H, Dunstan JA, Prescott SL. Effect of probiotic supplementation for the first 6 months of life on allergen- and vaccine-specific immune responses. Clin Exp Allergy. 2006;36:122736.

13. Prescott SL, Bjorksten S. Probiotic for the prevention or treatment of allergic diseases. J Allergy Clin Immunol. 2007;120:255-62.

14. Vijanen M, Pohjavuori E, Hactaela T. Korpella R, Kuitumen M, Sarnesto A, dkk. Induction of inflammation as a possible mechanism of probiotic effect in atopic eczema-deratitis syndrome. J Alllergy Clin Immunol. 2005;115:1254-9.

15. Rautava S, Kalliomaki M, Isolauri E. Probiotic during pregnancy and breatsfeeding might counter immunomodulatory protection against atopic disease in the infant. J Allergy Clin Immunol. 2002;109:119-21.

16. Ouwehand AC. Antiallergic effect of probiotics. J Nutr. 2007;137:7945-7.

17. Sarkar S. Therapeutic aspects of breast milk. Nut Food Science. 2004;34(3):108-12.

18. Arifeen S, Blace R, Gregtchen A, Baqui A, Becker S. Exclusive breastfeeding reduces acute respiratory infection and diarrhea deaths among infants in Dhaka Slums. Pediatrics. 2001;108(4):1-8.

19. Murphy K, Travers P, Walport M, penyunting. Janeway's immunobiology. Edisi ke-7. New York: Garland Science; 2008.

20. Weinberg EG. The atopic march. Current Allergy. 2005;18:4-5. 